\title{
CHANNEL AND BANK STABILITY OF WOLF CREEK AND A TRIBUTARY AT U.S. HIGHWAY 45 NEAR WHEELER, PRENTISS COUNTY, MISSISSIPPI
}

by K. Van Wilson, Jr. and D. Phil Turnipseed

U.S. GEOLOGICAL SURVEY

Open-File Report 90-110

Prepared in cooperation with the

MISSISSIPPI STATE HIGHWAY DEPARTMENT

Jackson, Mississippi

1990 


\section{DEPARTMENT OF THE INTERIOR \\ MANUEL LUJAN, JR., Secretary \\ GEOLOGICAL SURVEY \\ Dallas L. Peck, Director}

For additional information write to:

District Chief

U.S. Geological Survey

Suite 710, Federal Building 100 W. Capitol Street

Jackson, Mississippi 39269
Copies of this report can be purchased from:

U.S. Geological Survey

Books and Open-File Reports

Building 810

Box 25425, Federal Center

Denver, Colorado 80225 


\section{CONTENTS}

Page

Definition of terms........................................................................................ vi

Abstract....................................................................................................................... 1

Introduction .............................................................................................................. 2

Purpose and scope............................................................................................ 2

General description of Wolf Creek ............................................................. 2

Channel modifications to Wolf Creek, Wolf Creek north tributary, and Twentymile Creek..................................................................................... 2

Acknowledgments............................................................................................... 4

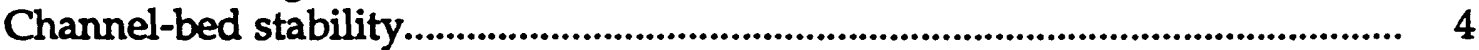

Botanical evidence of gradation ......................................................................... 4

Gradation analyses.................................................................................................. 4

Wolf Creek ........................................................................................................... 6

Wolf Creek north tributary ............................................................................... 9

Channel-bank stability.................................................................................. 9

Botanical evidence of widening ........................................................................ 9

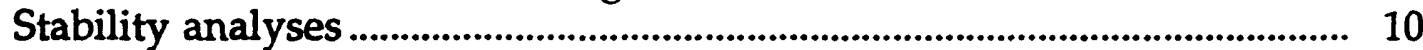

Wolf Creek....................................................................................... 10

Wolf Creek north tributary .................................................................... 11

Widening analyses .................................................................................. 11

Wolf Creek........................................................................................ 13

Wolf Creek north tributary ........................................................................ 16

Summary ...................................................................................................... 16

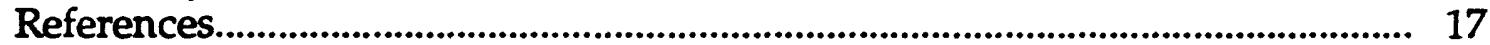




\section{ILLUSTRATIONS}

Page

Figure 1. Map showing the location of Wolf Creek and tributaries at existing U.S. Highway 45 and proposed U.S. Highway 45 relocation near Wheeler, Mississippi

2. Graph showing channel-bed profiles for Wolf Creek north tributary in the vicinity of the proposed U.S. Highway 45 relocation near Wheeler, Mississippi

3. Graph showing estimated patterns of channel-bed gradation processes on Wolf Creek at existing U.S. Highway 45 near Wheeler, Mississippi

4. Cross section showing critical failure surfaces for channel banks on Wolf Creek about 180 feet downstream from the proposed U.S. Highway 45 relocation near Wheeler, Mississippi.

5. Graph showing estimated patterns of channel widening on Wolf Creek at existing U.S. Highway 45 near Wheeler, Mississippi.

\section{TABLES}

Table 1. Channel-bed elevation and total degradation on Wolf Creek at existing U.S. Highway 45 near Wheeler, Mississippi

2. Dry bulk-unit weight and shear-strength properties of soil as determined from borehole tests on the right (south) bank of Wolf Creek about 180 feet downstream from the proposed U.S. Highway 45 relocation near Wheeler, Mississippi

3. Bankfull channel width and widening on Wolf Creek in the vicinity of existing U.S. Highway 45 near Wheeler, Mississippi 


\section{CONVERSION FACTORS}

For readers who may prefer to use the metric (International System) of units rather than the inch-pound units used herein, the conversion factors are listed below:

$\begin{array}{lccl}\text { Multiply inch-pound unit } & \text { by } & \text { To obtain metric unit } \\ \text { foot per second }(\mathrm{ft} / \mathrm{s}) & 0.3048 & \text { meter per second }(\mathrm{m} / \mathrm{s}) \\ \text { cubic foot per second }\left(\mathrm{ft}^{3} / \mathrm{s}\right) & 0.02832 & \text { cubic meter per second }(\mathrm{m} 3 / \mathrm{s}) \\ \text { foot }(\mathrm{ft}) & 0.3048 & \text { meter }(\mathrm{m}) \\ \text { foot per mile }(\mathrm{ft} / \mathrm{mi}) & 0.018939 & \text { meter per kilometer }(\mathrm{m} / \mathrm{km}) \\ \text { square foot }\left(\mathrm{ft}^{2}\right) & 0.09290 & \text { square meter }\left(\mathrm{m}^{2}\right) \\ \text { pounds per square foot }\left(\mathrm{lb} / \mathrm{ft}^{2}\right) & 47.88 & \text { newtons per square meter }\left(\mathrm{N} / \mathrm{m}^{2}\right) \\ \text { pounds per cubic foot }\left(\mathrm{lb} / \mathrm{ft}^{3}\right) & 157.09 & \text { newtons per cubic meter }\left(\mathrm{N} / \mathrm{m}^{3}\right) \\ \text { mile (mi) } & 1.609 & \text { kilometer }(\mathrm{km}) \\ \text { square mile }\left(\mathrm{mi}^{2}\right) & 2.590 & \text { square kilometer }\left(\mathrm{km}^{2}\right)\end{array}$

Mississippi State Highway Department Datum: In this report, elevations are referenced to Mississippi State Highway Department Datum (MSHDD), which is to the National Geodetic Vertical Datum of 1929 (NGVD of 1929)--a datum derived from a general adjustment of the first-order level nets of both the United States and Canada, formerly called Sea Level Datum of 1929 and referred to in this report as sea level. 


\section{DEFINITION OF TERMS}

Terms used in this report are defined below.

Angle of internal friction -angle of the plane of contact of soil particles with the horizontal at the point of sliding (shearing); angle whose tangent is the coefficient of friction between the soil particles (Cernica, 1982).

Channel-bed aggradation - filling in of the channel because streamflows are not sufficient to transport the material delivered from upstream channel-bed degradation (Simon and Hupp, 1986b).

Channel-bed degradation -headward erosion of the channel bed usually caused by increases in downstream channel gradient and crosssectional area by man (Simon and Hupp, 1986b).

Cohesion -attraction of adsorbed water and soil particles that produce a body, which holds together but deforms plastically at varying water contents (Sowers, 1979).

Critical bank height theight of channel bank above which failure can be expected, produced by an increased height (channelbed degradation) or bank angle (over steepening through erosion) (Thorne and others, 1981).

Dry bulk-unit weight -ratio of the weight of the soil solids to the volume of the soil sample (Das, 1984).

Factor of safety -ratio of the resisting force (shear strength of the soil) to the driving force (weight of the soil). If the resisting force is less than the driving force, the factor of safety is less than 1.0, and therefore, failure occurs (Huang, 1983).

Failure-block width -the measured width of the failure block or the distance between affected stems of woody plants growing in bank material that has failed and fallen down slope and the existing top-bank edge (Hupp, 1987).

Iowa Borehole Shear Test -direct measure of shear strength of fine- to medium-grained soils insitu (from inside a borehole) (Handy, 1981).
Knickpoint -an abrupt change in channel-bed elevation along a reach of channel relative to the upstream or downstream direction.

Moisture content -ratio of the weight of the water present to the weight of the soil solids (Das, 1984).

Planar failure -slides along a surface of rupture whereby the mass progresses down and out along a more or less planar or gentlyundulatory surface and has little rotational movement or backward tilting characteristics (Huang, 1983).

Rotational failure -landslide along a surface of rupture that is concave upward. The exposed cracks are concentric in plan and concave toward the direction of movement (Huang, 1983).

Shear strength -capacity of a soil to resist shear; in terms of effective stress, it can be given by the equation:

where:

$$
s^{\prime}=c^{\prime}+\sigma^{\prime} \tan \phi^{\prime}
$$

$\sigma^{\circ}=$ effective normal stress on plane of shear

$c^{\prime}=$ cohesion or apparent cohesion of the soil; and

$\phi^{\circ}=$ angle of internal friction.

(Das, 1984).

Slough-line angle -angle attained by projecting the slope of failed blocks of soil mass (which represents a temporary angle of stability) to its intersection with the top of channel bank (flood-plain level). It is used to determine short-term (10-20 years) bank widening (Simon and Hupp, 1986a).

Temporary angle of stability the angle from the horizontal extended from the toe to the top of bank in which that bank at that given height is the most stable. It can be estimated by averaging the existing bank angle with the angle of internal friction of the bank material. (Spangler and Handy, 1973). 


\title{
CHANNEL AND BANK STABILITY OF WOLF CREEK AND A TRIBUTARY AT U.S. HIGHWAY 45 NEAR WHEELER, PRENTISS COUNTY, MISSISSIPPI
}

\author{
by K. Van Wilson, Jr. and D. Phil Turnipseed
}

\begin{abstract}
The channel of Wolf Creek at the existing and proposed U.S. Highway 45 relocation near Wheeler, Mississippi, has degraded about 8 feet and widened about 122 feet since it was channelized in about 1912. Channel degradation of a small tributary to Wolf Creek has totaled about 2 feet in the vicinity of the proposed relocation. Botanical evidence indicates that several recent bank failures downstream from the proposed relocated crossing of Wolf Creek occurred as a result of floods in 1973, 1977, and 1987-88.

Rates of channel gradation and widening--as determined from channel descriptions and botanical evidence along the banks--were used in conjunction with soil properties to estimate probable future channel degradation and widening through the year 2010. By assuming that channelbed elevations can be expressed as a power function with time, additional channel degradation through the year 2010 could approach 3 feet at the existing and at the proposed crossing of Wolf Creek. No further significant degradation is expected at the proposed crossing of the small tributary to Wolf Creek. The bankfull channel width of Wolf Creek at the existing and at the proposed crossing could increase about 30 feet by the year 2010. The channel width of the northern tributary at the proposed crossing could increase about 10 feet in the next 10 to 20 years. These projections are based on the assumption that no additional channel modifications and no unusually large and destructive flooding will occur by the year 2010.
\end{abstract}




\section{INTRODUCTION}

The Mississippi State Highway Department proposes to relocate the U.S. Highway 45 crossing of Wolf Creek near Wheeler, Prentiss County, Mississippi (fig. 1). Because channel degradation and bank sloughing have occurred recently on Wolf Creek, the U.S. Geological Survey, in cooperation with the Mississippi State Highway Department, conducted a study of channel and bank stability of Wolf Creek at existing U.S. Highway 45 and of Wolf Creek and a small tributary at the proposed U.S. Highway 45 relocation.

\section{Purpose and Scope}

The purpose of this report is to describe the existing channel and bank conditions and present the results of a study to determine the potential for near-future (through the year 2010) degradation and widening of Wolf Creek at existing U.S. Highway 45 and of Wolf Creek and a small tributary at the proposed U.S. Highway 45 relocation near Wheeler, Mississippi. Past and present channel conditions were determined on the basis of field observations of channel-bed elevations, bank failures, ages and types of trees on the channel banks, and other botanical evidence. The potential for future degradation was estimated using power functions of past channel-bed elevations with time. The potential for future channel widening was estimated using both the potential for future bank failures (based on present channel geometry and the dry-bulk unit weights and shear-strength properties of the bank material) at the proposed relocation and application of power functions of past channel widths with time at existing U.S. Highway 45. This report is the fourth in a series of similar reports for selected stream crossings in Mississippi.

\section{General Description of Wolf Creek}

Wolf Creek is located in the Black Belt, East Gulf Coastal Plain physiographic region (Thornbury, 1965). The drainage area of Wolf Creek at the proposed U.S.
Highway 45 relocation is $22.7 \mathrm{mi}^{2}$ (square mile), and the length of the channel upstream of the site is about $8.7 \mathrm{mi}$. Average channel and valley slopes in the vicinity are about 6.7 and $3.8 \mathrm{ft} / \mathrm{mi}$ (feet per mile), respectively. The channel of Wolf Creek in the vicinity of the proposed relocation consists of sand and is fairly uniform; the channel banks average about $21 \mathrm{ft}$ in height. Wolf Creek flows into Twentymile Creek about $1.3 \mathrm{mi}$ downstream from the proposed crossing (about 2,000 ft upstream from existing U.S. Highway 45). The proposed relocation also crosses a northern and southern tributary of Wolf Creek about 1,600 and $4,000 \mathrm{ft}$ upstream, respectively, of where they flow into Wolf Creek (fig. 1). The northern tributary, which has undergone some degradation and widening, is included in the analyses described in this report. The southern tributary, which is characterized by dense vegetation and beaver dams, apparently has not undergone similar channel changes and is not discussed in this report. For convenience, the northern tributary of Wolf Creek is designated Wolf Creek north tributary in this report.

A pipeline crosses Wolf Creek about $50 \mathrm{ft}$ upstream from the proposed U.S. Highway 45 relocation. About a $2-\mathrm{ft}$ change in bed level exists between the upstream and downstream side of the pipeline.

\section{Channel Modifications to Wolf Creek, Wolf Creek North Tributary, and Twentymile Creek}

Wolf Creek was channelized from its mouth for about 5 miles upstream in about 1912 by the Wolf Creek Drainage District (Mississippi Board of Development, 1940c). In about 1923, Wolf Creek north tributary in the vicinity of the proposed relocation was channelized for about 1 mile upstream from its mouth by the Wolfe Creek Sub-drainage District No. 1 and interested landowners (Mississippi Board of Development, 1940d) (fig. 1).

The U.S. Army Corps of Engineers has constructed two grade-control structures downstream from the proposed relocation. 


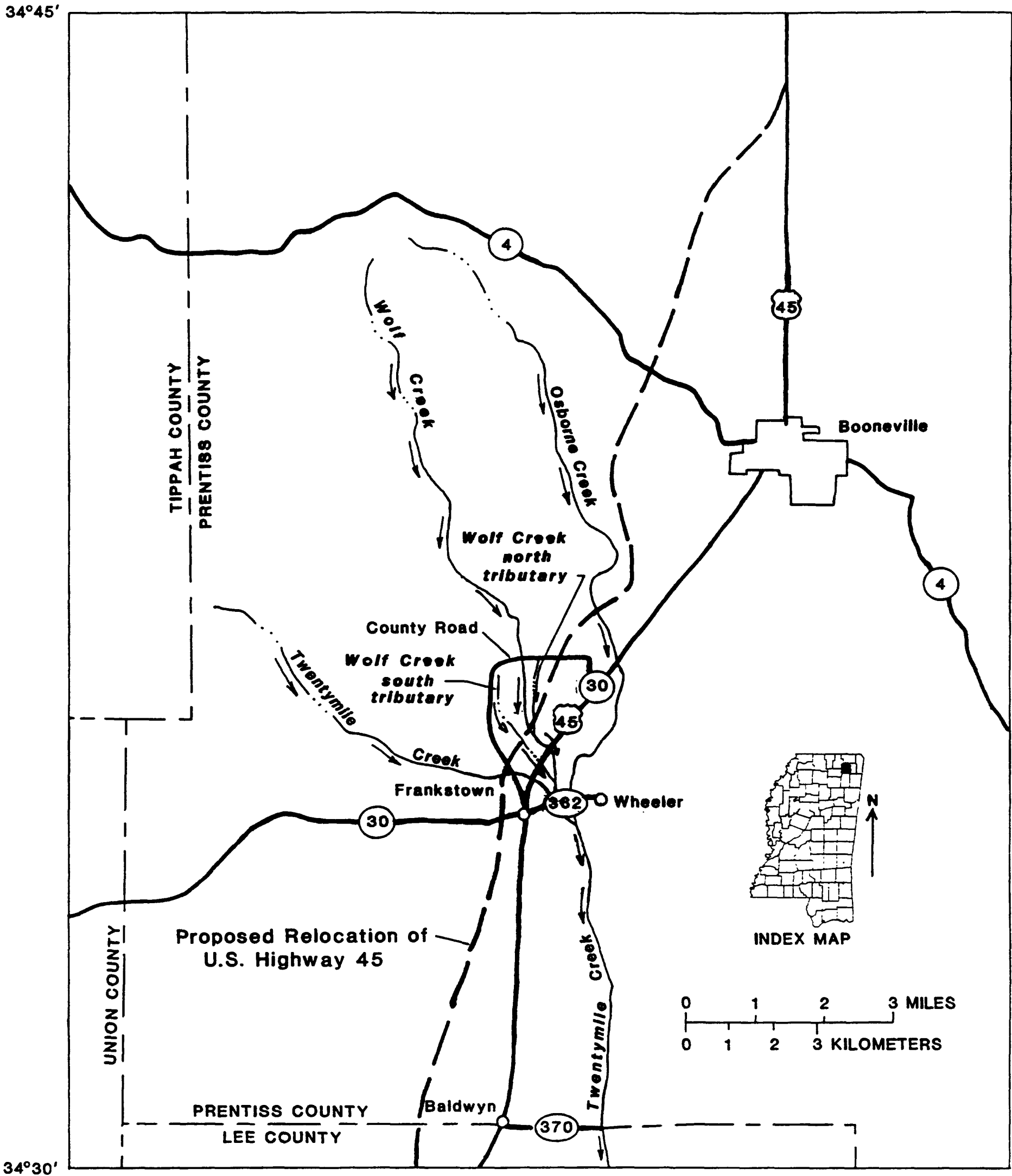

Figure 1.--Location of Wolf Creek at existing U.S. Highway 45 and proposed U.S. Highway 45 relocation near Wheeler, Mississippi. 
One structure located at State Highway 362 (about $1.3 \mathrm{mi}$ downstream from the proposed relocation) was completed in 1983, and the other, at existing U.S. Highway 45 (about $2,000 \mathrm{ft}$ downstream from the proposed relocation) was completed in 1984 (D.C. Otto, U.S. Army Corps of Engineers, oral commun., 1988).

About 1912, the Prentiss County Twenty Mile Drainage District excavated a ditch about $\mathbf{5 . 1}$ mile long, which approximately followed the natural drainage channel of Twentymile Creek from the Prentiss-Lee County line (in the vicinity of State Highway 370) to the vicinity of State Highway 362 (Mississippi Board of Development, 1940b). At about the same time, the Lee County Twenty Mile Drainage District excavated a ditch about $7.4 \mathrm{mi}$ long from the Prentiss-Lee County line to the LeeItawamba County line (Ramser, 1930), and the Itawamba County Twenty Mile Drainage District channelized the reach of Twentymile Creek from the Lee-ltawamba County line to the mouth (Mississippi Board of Development, 1940a). This downstream reach was channelized again in 1966 by the U.S. Army Corps of Engineers. A bankstabilization project was undertaken by the Corps of Engineers in 1981 to prevent further bank failures and erosion that began shortly after the 1966 channel-modification project was completed in the lower reaches of Twentymile Creek. This project consisted of numerous grade-control structures on Twentymile Creek and selected tributaries. Also, willows and reed grass were planted in order to provide protection along erodible banks in selected areas along Twentymile Creek (U.S. Army Corps of Engineers, 1983). A project to study the effects of the gradecontrol structures is currently being conducted by the Waterways Experiment Station in Vicksburg, Mississippi (D.C. Otto, U.S. Army corps of Engineers, oral commun., 1988).

\section{Acknowledgments}

The authors are indebted to members of the Mississippi State Highway Department, Hydraulics Division, who provided bridge-inspection records, and to members of the Department's Soil Mechanics
Laboratory, who assisted in the analysis of soil samples. The authors also acknowledge personnel of the U.S. Army Corps of Engineers, who provided channel cross sections and profiles.

\section{CHANNEL-BED STABILITY}

\section{Botanical Evidence of Gradation}

Trees growing below tops of banks can indicate rates of channel gradation. Trees establish a root collar at the ground surface during germination (Simon and Hupp, 1986a). The thickness of sediment burial or the depth of exhumation relative to the root collar define the degree of aggradation or degradation, respectively. Exhumation from the root collar of trees growing below bankfull level indicated that, prior to substantial degradation, the elevation of the channel bed about $800 \mathrm{ft}$ downstream from existing U.S. Highway 45 was about 8 to $10 \mathrm{ft}$ above the existing channel bed. The channel bed at the mouth of Wolf Creek north tributary (about 1,600 ft downstream from the proposed crossing of the tributary) was also about 8 to $10 \mathrm{ft}$ above the existing channel bed prior to substantial degradation. In the channel reach from 550 to $900 \mathrm{ft}$ downstream from the proposed crossing of the tributary, the channel bed was about 5 to $6 \mathrm{ft}$ above the existing channel bed (fig. 2).

A $31 / 2-\mathrm{ft}$ knickpoint exists on the clay channel bed of Wolf Creek north tributary about $1,100 \mathrm{ft}$ upstream from its mouth at Wolf Creek. Botanical evidence in the area indicates this knickpoint represents a gradual headward-progressing degradation process (fig. 2).

\section{Gradation Analyses}

On an alluvial stream undergoing morphologic change in response to channel modifications, channel gradation processes generally start at a high rate and diminish with time. Studies of channel-gradation processes on alluvial streams have shown that channel-bed elevation can be expressed as a power function with time (Simon and Hupp, 1986b) in the general form: 


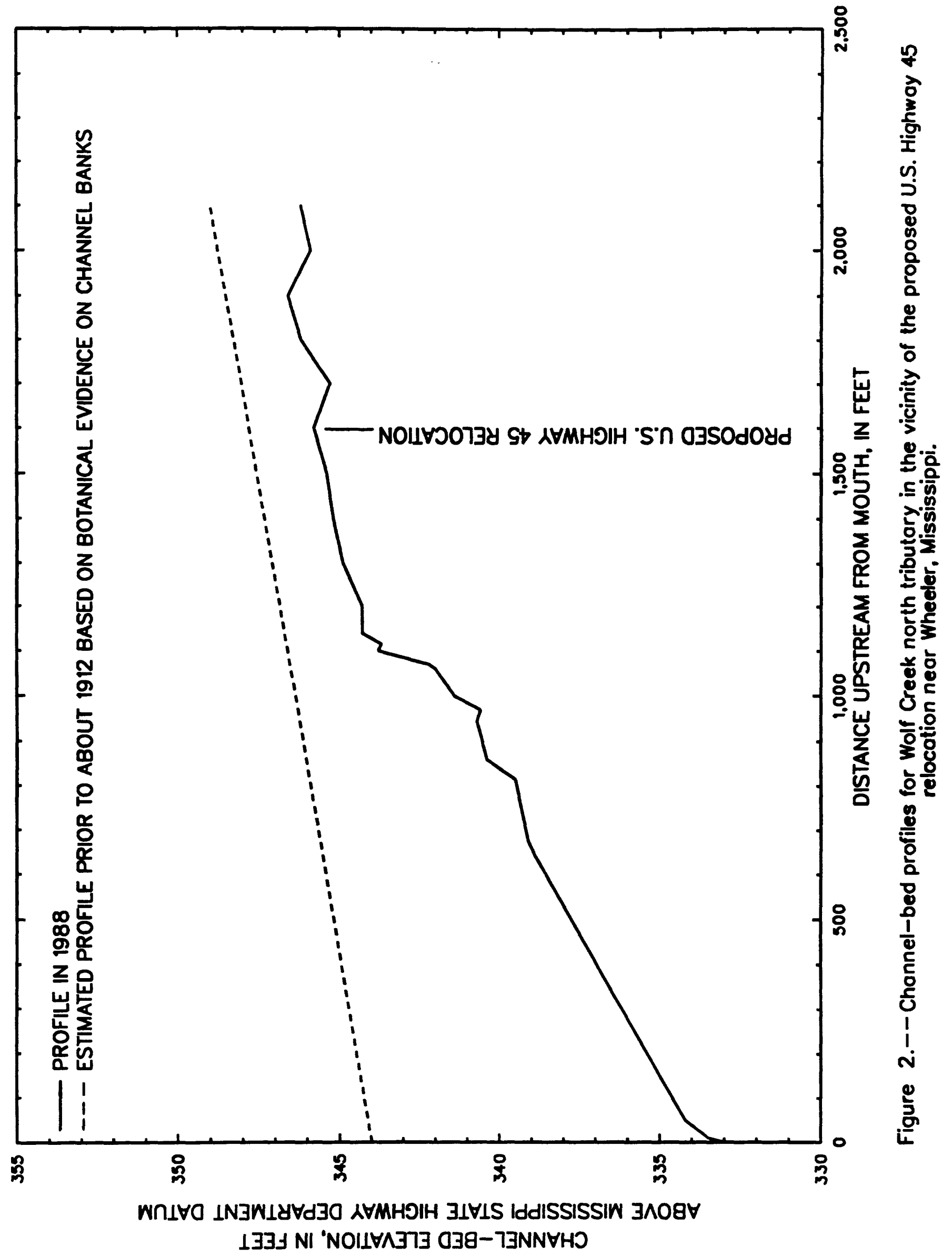




$$
E=a \cdot t^{b}
$$

$$
\begin{aligned}
& \text { where } \\
& \mathbf{E}=\text { elevation of the channel bed, in } \\
& \text { feet above sea level; } \\
& \text { a }=\text { regression constant, indicative of } \\
& \text { channel-bed elevation prior to } \\
& \text { the onset of the gradation } \\
& \text { process in response to channel } \\
& \text { modification, in feet above sea } \\
& \text { level; } \\
& t=\text { time, in years since beginning of } \\
& \text { the gradation process }(t=1 \\
& \text { during the first year of channel } \\
& \text { adjustment); and } \\
& \text { b }=\text { regression coefficient indicative } \\
& \text { of the rate of the gradation } \\
& \text { process (negative for } \\
& \text { degradation and positive for } \\
& \text { aggradation). }
\end{aligned}
$$

Datums other than sea level for channelbed elevations $(E)$ in equation 1 may be used for convenience (for example, when sea level datum is not readily available at a site), but this will affect values of $a$ and $b$. If elevations above the assumed datum are greater than the elevations obtained when referenced to sea level datum, the value of a will increase, but the absolute value of $b$ will decrease. Conversely, if elevations above the assumed datum are less than the elevations obtained when referenced to sea level datum, the value of a will decrease, but the absolute value of $b$ will increase. Also, by varying the datum, an imposed logarithmic offset for the log-linear relation will change, thus, in some cases, improving or worsening the log-linear statistical fit of the data points. In previous studies, the effects of channel-bed elevations on gradation trends were analyzed by varying the datum of the study sites, the analysis indicated no significant effects on the gradation estimates (Andrew Simon, U.S. Geological Survey, oral commun., 1988). Elevations in this report were referenced to
Mississippi State Highway Department Datum, which is to sea level datum.

\section{Wolf Creek}

It is assumed that the general form of equation 1 is applicable for estimating channel-bed gradation processes through the year 2010 on Wolf Creek. Channel-bed gradation processes in the past are assumed to be representative of those in the near future. This assumption could be negated by additional channel modifications or the occurrence of unusually large, destructive flooding, which could alter ongoing gradation processes.

The channel-bed elevations used in these analyses were obtained from surveys and inspections made by the Mississippi State Highway Department, the U.S. Army Corps of Engineers, the U.S. Department of Agriculture, and the U.S. Geological Survey (table 1). Some differences in channel-bed elevations may not be absolutely indicative of actual change. The channel-bed elevations used to analyze gradation were obtained at the existing U.S. Highway 45 bridge; no significant evidence of localized scour was observed. Localized scour at a bridge occurs when flow velocities are increased for a short distance upstream and downstream from the bridge. Increased velocities are caused by the cross sectional area being substantially reduced by bridgeapproach embankments, piers, and other obstructions. However, a scour hole is present just downstream from the gradecontrol structure. The scour hole is the result of increased flow velocities produced by the increase in channel gradient through the structure. The scour hole has no significant effect on channel-bed elevations given in table 1, because all of the elevations were obtained prior to the construction of the structure except the 1988 elevation, which was surveyed just upstream from the bridge. The effect of localized scour would be an addition or a subtraction to the ongoing degradation or aggradation processes, respectively, and therefore would not be representative of the selected reach of channel studied. 
Table 1.--Channel-bed elevation and total degradation on Wolf Creek at existing U.S. Highway 45 near Wheeler, Mississippi

\begin{tabular}{lcc}
\hline Year & $\begin{array}{c}\text { Channel-bed elevation } \\
\text { (feet above Mississippi State } \\
\text { Highway Department Datum) }\end{array}$ & $\begin{array}{c}\text { Total } \\
\text { degradation since 1912 } \\
\text { (feet) }\end{array}$ \\
\hline & 1339.0 & \\
1912 & 334.9 & 0.0 \\
1936 & 333.4 & 4.1 \\
1938 & 332.0 & 5.6 \\
1954 & 333.7 & 7.0 \\
1962 & 333.9 & 5.3 \\
1975 & 331.2 & 5.1 \\
1977 & 333.6 & 7.8 \\
1980 & 330.7 & 5.4 \\
1988 & & 8.3 \\
\hline
\end{tabular}

1 Estimated based on botanical evidence downstream of existing U.S. Highway 45 and a 10 -foot channel-design depth used for Twentymile Creek (Ramser, 1930)

Channel gradation processes at existing U.S. Highway 45 appear to be representative of processes about $2,000 \mathrm{ft}$ upstream at the proposed relocation. At the proposed relocation, channel-bed elevations were estimated from channel-bed profiles surveyed in 1975 and 1980 and from a 1988 cross section. The elevations indicated about a $4 \mathrm{ft}$ decrease between 1975 and 1988, which was reasonably consistent with the $3.2 \mathrm{ft}$ decrease at existing U.S. Highway 45 (table 1).

Available data from 1912 to 1988 indicate channel-bed degradation totaling about $8 \mathrm{ft}$ on Wolf Creek at existing U.S. Highway 45 (table 1). Significant variation in the data motivated the use of two possible scenarios to project near-future degradation on Wolf Creek. For the first scenario, a log-linear regression of all available channel-bed elevations (except 1962, 1975, and 1980) with respective times was used to define a channel-bed degradation relation $\left(E=339.4 t^{-0.00556}\right.$, where $t$ is time in years since 1912). The 1962, 1975, and 1980 channel-bed elevations were omitted because they represented a temporary fill or possibly have a datum problem. The first scenario projected no significant further degradation by the year 2010 (fig. 3).
The second scenario was based on the assumption that the March 1955 flood and the May 1983 flood altered the ongoing degradation process that began in 1912 . These floods could have had recurrence intervals of about 25 years. Data from 1962 to 1980 (table 1), with the exception of the 1977 elevation, indicate aggradation. The 1977 elevation was omitted because it possibly represented a temporary scour or reflects a datum problem. Therefore, Wolf Creek possibly underwent degradation from 1912 to 1955 , aggradation from 1955 to 1983 , and degradation from 1983 to 1988 . Loglinear regression of channel-bed elevation with time was used to define a channelgradation relation for each time period: 1912 to $1955\left(E_{d 1}=339.1 t_{d 1}-0.00500\right.$, where $t_{d 1}$ is time, in years since 1912), 1955 to 1983 $\left(E_{a}=332.8 t_{a}+0.000980\right.$, where $t_{a}$ is time, in years since 1955) and 1983 to 1988 $\left(E_{d 2}=333.9 t_{d 2}-0.00537\right.$, where $t_{d 2}$ is time, in years since 1983). The second scenario projected about $3 \mathrm{ft}$ of further degradation by the year 2010 (fig. 3). The grade control structure and chalk outcrop located downstream should reduce the probability of degradation. However, because of the sandy composition of this streambed, much of the bed could possibly be in movement during an extreme flood. 


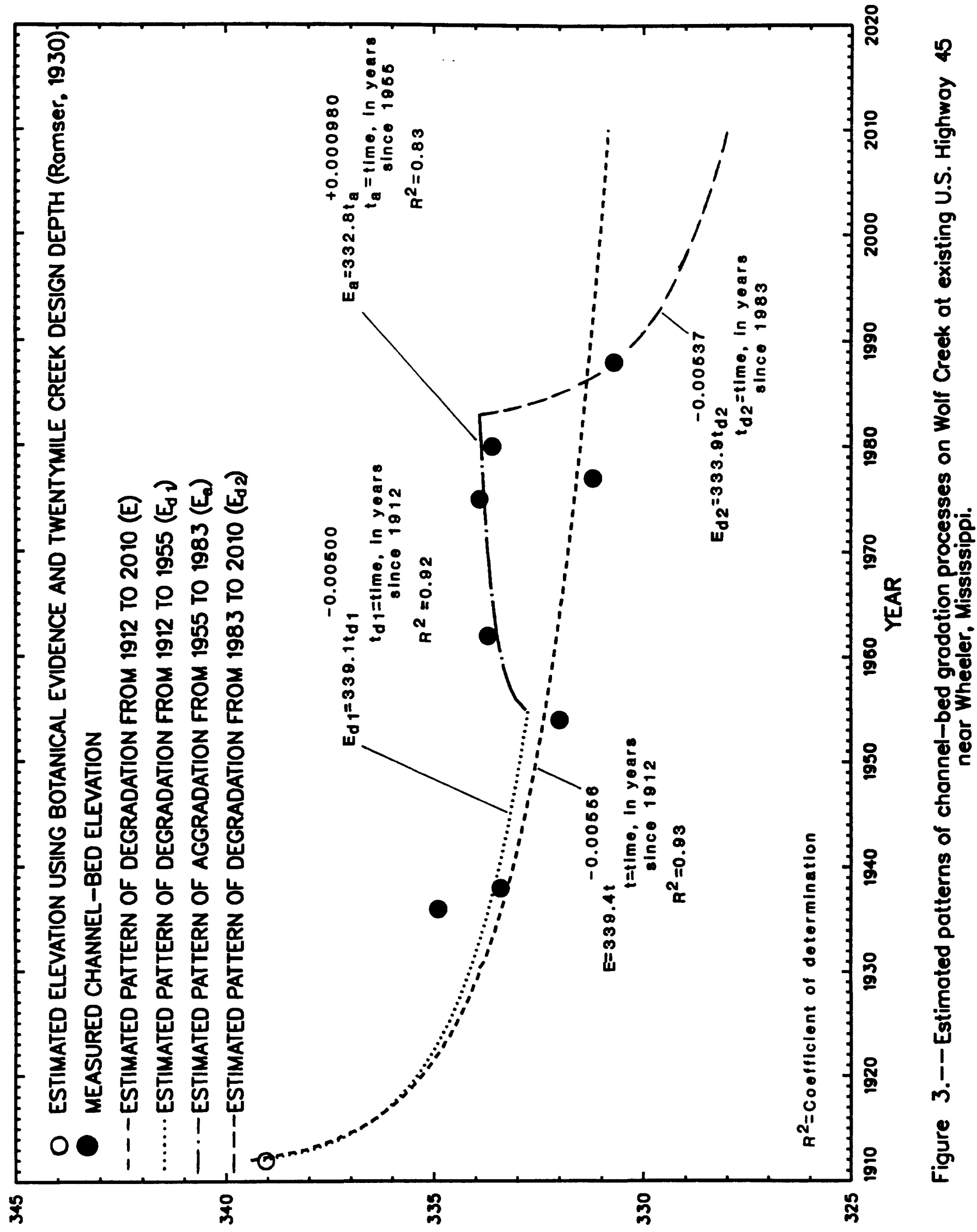

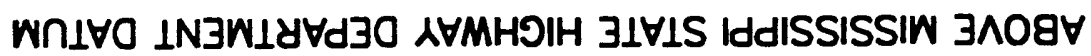

$13 \exists \exists$ NI ‘NOII $\forall \wedge 37 \exists$ 
In summary, the channel bed of Wolf Creek at existing U.S. Highway 45 has degraded about $8 \mathrm{ft}$ since 1912. Channel-bed gradation processes at existing U.S. Highway 45 appear to be representative of processes at the proposed relocation. As much as $3 \mathrm{ft}$ of further degradation through the year 2010 could occur on Wolf Creek at existing U.S. Highway 45 and at the proposed relocation.

\section{Wolf Creek North Tributary}

Channel-bed elevations for use in equation 1 for Wolf Creek north tributary at the proposed relocation were limited to a botanical estimate of about $348 \mathrm{ft}$ prior to substantial degradation and a 1988 measurement of about $346 \mathrm{ft}$ (fig. 2). If degradation began at the proposed relocation in about 1923 when the tributary was channelized, the channel bed has degraded about $2 \mathrm{ft}$ in 66 years. A log-linear regression of the two elevations with respective times to develop an equation in the general form of equation 1 indicated no significant further degradation by the year 2010 at the proposed relocation.

The 3/2-ft knickpoint about $500 \mathrm{ft}$ downstream from the proposed relocation (fig. 2) could have started progressing upstream from the mouth of the north tributary as early as about 1912 when Wolf Creek was channelized. The knickpoint has progressed about $1,100 \mathrm{ft}$ in about 77 years if it started in 1912 or 66 years if it started progressing upstream in 1923. Based on these rates of progression, it could take 30 to 35 years for the knickpoint to progress upstream to the proposed relocation. This simple linear extension should yield a conservatively low estimate of time because degradation usually diminishes with time. Therefore, no significant further degradation could reasonably be expected on Wolf Creek north tributary at the proposed relocation by the year 2010 .

\section{CHANNEL-BANK STABILITY}

\section{Botanical Evidence of Widening}

Bank failures along unstable reaches may kill, tilt, or scar existing woody plants, and create fresh surfaces upon which plants may become established. Scars and sprouts from parental stems of tilted plants yield accurate dates (within 1 year, often within one season) of bank failures (Hupp, 1987. 1988; Sigafoos, 1964).

Eccentric growth, resulting in anomalous tree-ring series, occurs when the stem is inclined. This type of growth is determined easily from tree cross sections where concentric-ring formation abruptly becomes eccentric with ring width greater in the upslope direction. Eccentric-ring patterns yield highly accurate dates, usually accurate within one season, of tilting. Dating of stems that have established on disturbed surfaces yields minimum ages for the surfaces (Simon and Hupp, 1986a).

Trees growing on unstable bank surfaces along Wolf Creek near the proposed relocation show effects of recent bank sloughing in their stem morphology, anatomy, and ages. Channel banks on both sides of the stream appear to have sloughed recently in a combination of planar and rotational failures. Botanical data were collected by taking cross sections or increment borings of sprouts from tilted trees and of saplings and mature trees (such as hickory, sweet gum, alder, and willow) to determine their ages and by measuring bank failureblock widths. These data indicate that on the right (south) bank, a 10-ft-wide bank failure located $200 \mathrm{ft}$ downstream from the proposed relocation occurred in about 1973, a 4- to 5-ft-wide failure (at about mid bank) located about $600 \mathrm{ft}$ downstream occurred in 1987-88, and a 4- to 5-ft-wide failure located about $500 \mathrm{ft}$ downstream occurred in about 1977. On the left (north) bank, a 2- to 3-ftwide failure located about $500 \mathrm{ft}$ downstream from the proposed relocation occurred in 1987-88. These bank failures indicate that the critical bank height has been exceeded.

The left bank just downstream of the proposed relocation is being undercut by streamflows and is virtually without vegetation in some places. Some of the undercutting may be attributed to debris collecting on the pipeline crossing (about 
Table 2.-Dry bulk-unit weight and shear-strength properties of soil as determined from borehole tests on the right (south) bank of Wolf Creek about 180 feet downstream from the proposed U.S. Highway 45 relocation near Wheeler, Mississippi

[ft, foot; $\mathrm{lb} / \mathrm{ft}^{2}$, pounds per square foot; $\mathrm{lb} / \mathrm{ft}^{3}$, pounds per cubic foot]

\begin{tabular}{lcccc}
\hline $\begin{array}{l}\text { General } \\
\text { soil description }\end{array}$ & $\begin{array}{c}\text { Borehole } \\
\text { depth } \\
(\mathrm{ft})\end{array}$ & $\begin{array}{c}\text { Dry } \\
\text { bulk-unit } \\
\text { weight } \\
\left(\mathrm{lb} / \mathrm{ft}^{3}\right)\end{array}$ & $\begin{array}{c}\text { Cohesion } \\
\left(\mathrm{lb} / \mathrm{ft}^{2}\right)\end{array}$ & $\begin{array}{c}\text { Angle of } \\
\text { internal friction } \\
\text { (degrees) }\end{array}$ \\
\hline $\begin{array}{l}\text { Dark brown, } \\
\text { silty-sandy clay }\end{array}$ & $0-4.5$ & 99 & 220 & 31.5 \\
Orange-gray clay & $4.5-11.8$ & 100 & 450 & 16.6 \\
Gray, chalky sand & $11.8-18.5$ & 110 & 150 & 20.2 \\
\hline
\end{tabular}

$50 \mathrm{ft}$ upstream from the proposed relocation), causing the flows to be directed into the left bank. Grass and 2- to 3-year-old willow trees were present in places on the left bank; whereas, the right bank was more stable and had older trees that were used to date past bank failures.

Trees growing on bank surfaces along the Wolf Creek north tributary were about 50 years old and indicated that bank failures have been relatively small and infrequent since it was channelized. It should be noted that botanical evidence of previous bank failures may have been obscured with time and(or) by succeeding large floods (Simon and Hupp, 1986a).

\section{Stability Analyses \\ Wolf Creek}

Shear-strength properties of the channel banks were determined on the right (south) bank of Wolf Creek about $180 \mathrm{ft}$ downstream from the proposed relocation with the Iowa
Borehole Shear Tester ${ }^{1}$ (BST), (Handy and Fox, 1967). Dry bulk-unit weight and shearstrength properties of soil obtained at the site are given in table 2 . The average moisture content of the soil during testing was about 23 percent.

Shear-strength data obtained using the BST has compared reasonably well with the results of other standard laboratory procedures for the determination of soil strength (Wilson and Turnipseed, 1989a; Thorne and others, 1981). BST results for individual soil strata were used in stability analyses.

The factor of safety is the ratio of the resisting force (shear-strength of the bank material) to the driving force (weight of the bank material). Therefore, if the resisting force is equal to the driving force then the factor of safety is 1.0. Theoretically, when the factor of safety is less than 1.0, failure occurs, and when it is greater than 1.0, failure does not occur. This is based on the

\footnotetext{
${ }^{1}$ The use of trade or product names in this report is for identification purposes only, and does not constitute endorsement by the U.S. Geological Survey.
} 
assumption that all the forces have been considered. A factor of safety of at least 1.5 generally is used in design. Factors of safety for bank failures at selected percentages of bank saturation were determined by using dry bulk-unit weight and shear-strength properties of the bank material at a typical cross section just downstream from the proposed crossing of Wolf Creek. Computer programs REAME (Rotational Equilibrium Analysis of Multilayered Embankments) and SWASE (Sliding Wedge Analysis of Sidehill Embankments) developed by Huang (1983) were used to perform an iterative search to determine the minimum factor of safety for each percentage of bank saturation analyzed.

Analysis of both planar and rotationalbank failures indicated rotational-bank failures were more critical. Factors of safety computed at 0 - to 100-percent bank saturation ranged from 1.48 to 0.97 for the left bank and from 1.98 to 1.27 for the right bank. The left bank (existing bank angle about 41 degrees) fails at 100-percent saturation and is susceptible to failure (factor of safety less than 1.5) between 0and 100-percent saturation, and the right bank (existing bank angle about 23 degrees) becomes susceptible to failure between 75 - to 100-percent saturation. The critical rotational-failure surfaces with their respective factors of safety for 100 -percent bank-saturation conditions are shown in figure 4. On the right (south) bank, the failure-block width is about $13 \mathrm{ft}$, and on the left (north) bank, failure-block width is about $6 \mathrm{ft}$. Similar failure-block widths were observed in the field.

Factors of safety for rotational-bank failures were also computed assuming $3 \mathrm{ft}$ of further channel-bed degradation through the year 2010 as projected by the second channel-bed gradation scenario. This was done by lowering the elevation of the toe of each bank of the cross section by $3 \mathrm{ft}$. Factors of safety computed at 0 - to 100 -percent bank saturation ranged from 1.38 to 0.97 and from 1.36 to 1.05 . for the left and right banks, respectively. The factors of safety for the left bank were about the same as without degradation, but for the right bank, factors of safety for 0 - and 100-percent bank saturation were reduced. For 100-percent bank-saturation conditions, the failure block width decreased about $5 \mathrm{ft}$ on the right (south) bank and increased about $8 \mathrm{ft}$ on the left (north) bank as compared to failureblock widths as shown in figure 4. The failure-block width on the right bank decreased because the bank was destabilized with the increase in bank height and removal of supporting soil at the toe. Without degradation the right bank appeared to be fairly stable.

\section{Wolf Creek North Tributary}

Factors of safety for rotational bank failures at a typical cross section of the Wolf Creek north tributary located about $550 \mathrm{ft}$ downstream from the proposed relocation were computed at 0 - to 100 -percent bank saturation. Because no soil borings were obtained at the north tributary, the soil strata obtained at Wolf Creek were assumed to be representative of the north tributary. Factors of safety ranged from 3.12 to 2.00 , indicating the banks of the Wolf Creek north tributary in the vicinity of the proposed relocation are stable; as was indicated by the botanical evidence on the channel banks.

\section{Widening Analyses}

Channel-widening processes on an alluvial stream undergoing morphologic change in response to channel modifications generally start at a high rate and diminish with time. Channel-bed degradation increases bank heights and angles and causes channel widening by mass wasting. Depending on the soil properties of the bank material, some time generally elapses between the beginning of degradation and the beginning of widening. In this report, the time interval is assumed to be negligible because of insufficient data to support any other assumption. If enough channel-width information is a vailable, a power function of bankfull channel width with time, a technique used by Wilson and Turnipseed (1989b), can be developed in the general form: 


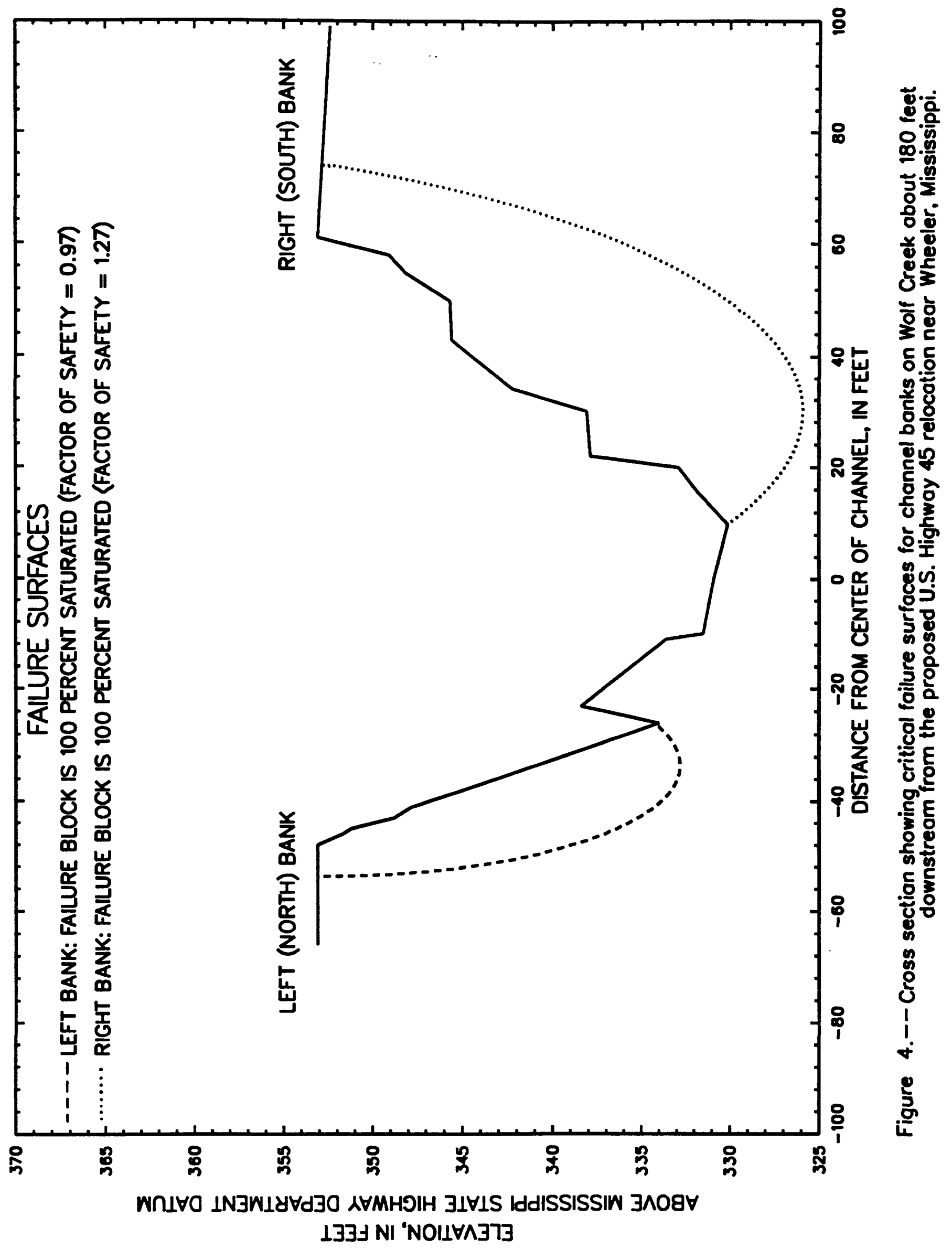




$$
w=c \cdot t^{d}
$$

where

$$
\begin{aligned}
& \mathbf{W}=\text { bankfull channel width, in } \\
& \text { c = regression constant, indicative } \\
& \text { of bankfull width prior to the } \\
& \text { onset of widening processes in } \\
& \text { response to channel } \\
& \text { modification, in feet; } \\
& t \text { = time, in years since beginning } \\
& \text { of the widening process, }(t=1 \\
& \text { during first year of channel } \\
& \text { adjustment); and } \\
& \mathbf{d}=\text { regression coefficient } \\
& \text { indicative of the rate of } \\
& \text { widening. }
\end{aligned}
$$

Channel-widening processes in the past are assumed to be representative of those in the near future. This assumption could be negated by additional channel modifications or the occurrence of unusually large, destructive flooding that could alter the ongoing widening processes.

Estimates of additional widening during the next 10 to 20 years can be obtained by projecting the streambank slough-line angle on a plotted cross section (Simon and Hupp, 1986a). Projection of this slough-line angle on the banks is used where conditions are stable and vegetation is well established. On banks where a slough line has not developed, a temporary angle of stability can be estimated by averaging the angle of internal friction of the bank material and the existing bank angle, a technique developed by Spangler and Handy (1973).

\section{Wolf Creek}

Estimates of near-future widening for Wolf Creek were obtained by use of the two methods as previously presented. Also, bankfull channel widths for Twentymile Creek at existing U.S. Highway 45 and widths for Wolf Creek at existing U.S. Highway 45 were compared, and channelbank stability analyses results were used in conjunction with channel-bed gradation analyses results. All four methods were used to determine a reasonable estimate of additional widening that could occur through the year 2010 .

Enough channel-width information was available to develop a power function of bankfull channel width with time (equation 2) at existing U.S. Highway 45. As with channel-bed elevations, the widths used in equation 2 were obtained from surveys and inspections made by the Mississippi State Highway Department, the U.S. Army Corps of Engineers, the U.S. Department of Agriculture, and the U.S. Geological Survey (table 3). Some changes in width may not be absolutely indicative of actual change. The bankfull widths were derived from surveys made by different agencies and may not reflect exactly the same location(s). Thus, there are inherent uncertainties in the interpretation of these data.

Table 3.--Bankfull channel width and total widening on Wolf Creek in the vicinity of existing U.S. Highway 45 near Wheeler, Mississippi

\begin{tabular}{ccc}
\hline Year & $\begin{array}{c}\text { Bankfull } \\
\text { channel width } \\
\text { (feet) }\end{array}$ & $\begin{array}{c}\text { Total widening } \\
\text { since 1912 } \\
\text { (feet) }\end{array}$ \\
\hline 1912 & 125 & 0 \\
1936 & 105 & 80 \\
1938 & 104 & 79 \\
1954 & 115 & 90 \\
1980 & 120 & 95 \\
1988 & 147 & 122 \\
\hline
\end{tabular}

${ }^{1}$ Estimated based on assumption that channel-design width used for Twentymile Creek (Ramser, 1930) was also used for Wolf Creek

Channel-widening processes at existing U.S. Highway 45 appear to be representative of processes about $2,000 \mathrm{ft}$ upstream at the proposed relocation. The 1988 width of $147 \mathrm{ft}$ at existing U.S. Highway 45 (table 3 ) is about 1.3 times the 
width of about $109 \mathrm{ft}$ at the proposed relocation.

Available channel-width data from 1936 to 1988 indicated that the Wolf Creek channel widened about $42 \mathrm{ft}$ at existing U.S. Highway 45 (table 3 ). Assuming that the channel-design width of $25 \mathrm{ft}$ used for Twentymile Creek (Ramser, 1930) was also used for Wolf Creek, the channel has widened about 122 feet during 77 years. Two possible scenarios were analyzed at this site using the channel-width data to project near-future widening. For the first scenario, a log-linear regression of all available channel widths with respective times was used to define a channel-widening relation $\left(W=26.1 t^{+0.396}\right.$, where $t$ is time in years since 1912). The first scenario projected $14 \mathrm{ft}$ of further widening by the year 2010 at existing U.S. Highway 45 (fig. 5).

The second scenario was based on the assumption that the March 1955 flood and the May 1983 flood altered the ongoing widening process that began in 1912 . Channel-width data (table 3) indicate no significant widening from 1954 to 1980 , probably because the possible aggradation from 1955 to 1983 affected the channelwidening process on Wolf Creek. Therefore, Wolf Creek underwent widening from 1912 to 1955 , no widening from 1955 to 1983 , and widening from 1983 to 1988 . Log-linear regression of channel width with time was used to define a channel-widening relation from 1912 to $1955\left(W_{1}=25.2 t_{1}^{+0.426}\right.$, where $t_{1}$ is time in years since 1912) and from 1983 to $1988\left(W_{3}=118 t_{3}+0.123\right.$, where $t_{3}$ is time, in years since 1983). The 1954 and 1980 channel widths were averaged to estimate the width $\left(W_{2}=118\right)$ from 1955 to 1983 . The second scenario projected about $30 \mathrm{ft}$ of further widening by the year 2010 at existing U.S. Highway 45 (fig. 5).

Slough lines and temporary angles of stability were also used to estimate additional channel widening during the next 10 to 20 years. Just upstream of existing U.S. Highway 45, as much as $10 \mathrm{ft}$ of additional widening was projected during the next 10 to 20 years and at the proposed relocation, as much as $14 \mathrm{ft}$ of additional widening was projected. These estimates agreed reasonably well with the value of $14 \mathrm{ft}$ from the first scenario.

A comparison of bankfull channel width for Wolf Creek and Twentymile Creek at existing U.S. Highway 45 for each respective time was made by dividing the width of Wolf Creek by width of Twentymile Creek. The width ratios were $1.59,1.73,1.42,1.41$, and 1.50 for 1936, 1938, 1954, 1980, and 1988, respectively. For Twentymile Creek, $15 \mathrm{ft}$ of additional widening was estimated to occur by the year 2010, producing a channel width of about $113 \mathrm{ft}$ (Turnipseed and Wilson, 1990). Multiplying the channel width of $113 \mathrm{ft}$ by 1.5, the width of Wolf Creek at existing U.S. Highway 45 is estimated to be about $170 \mathrm{ft}$ by the year 2010 ( $23 \mathrm{ft}$ wider than the 1988 width).

Factors of safety for bank failures, as previously presented, indicated bank failures will occur with or without further degradation. For existing bank conditions, the left bank will fail (factor of safety $=0.97$ ) with a failure-block width of about $6 \mathrm{ft}$; the right bank is susceptible to failure, but still has a factor of safety greater than 1.0 . If $3 \mathrm{ft}$ of further channelbed degradation occurs through the year 2010, failure will likely occur on the right bank (factor of safety $=1.05$ ) with a failureblock width of about $8 \mathrm{ft}$. If the left-bank failure material remains at the lower bank forming a sloughline, about $14 \mathrm{ft}$ of additional widening could occur through about the year 2010. If the sloughline does not form on the left bank, more than $14 \mathrm{ft}$ of additional widening could occur.

In summary, the channel at existing U.S. Highway 45 has widened about $122 \mathrm{ft}$ since about 1912. Channel-widening processes at existing U.S. Highway 45 appear to be representative of processes at the proposed relocation. Using four methods of estimating future widening, about $30 \mathrm{ft}$ of additional widening through the year 2010 could occur at existing U.S. Highway 45 and at the proposed relocation. 


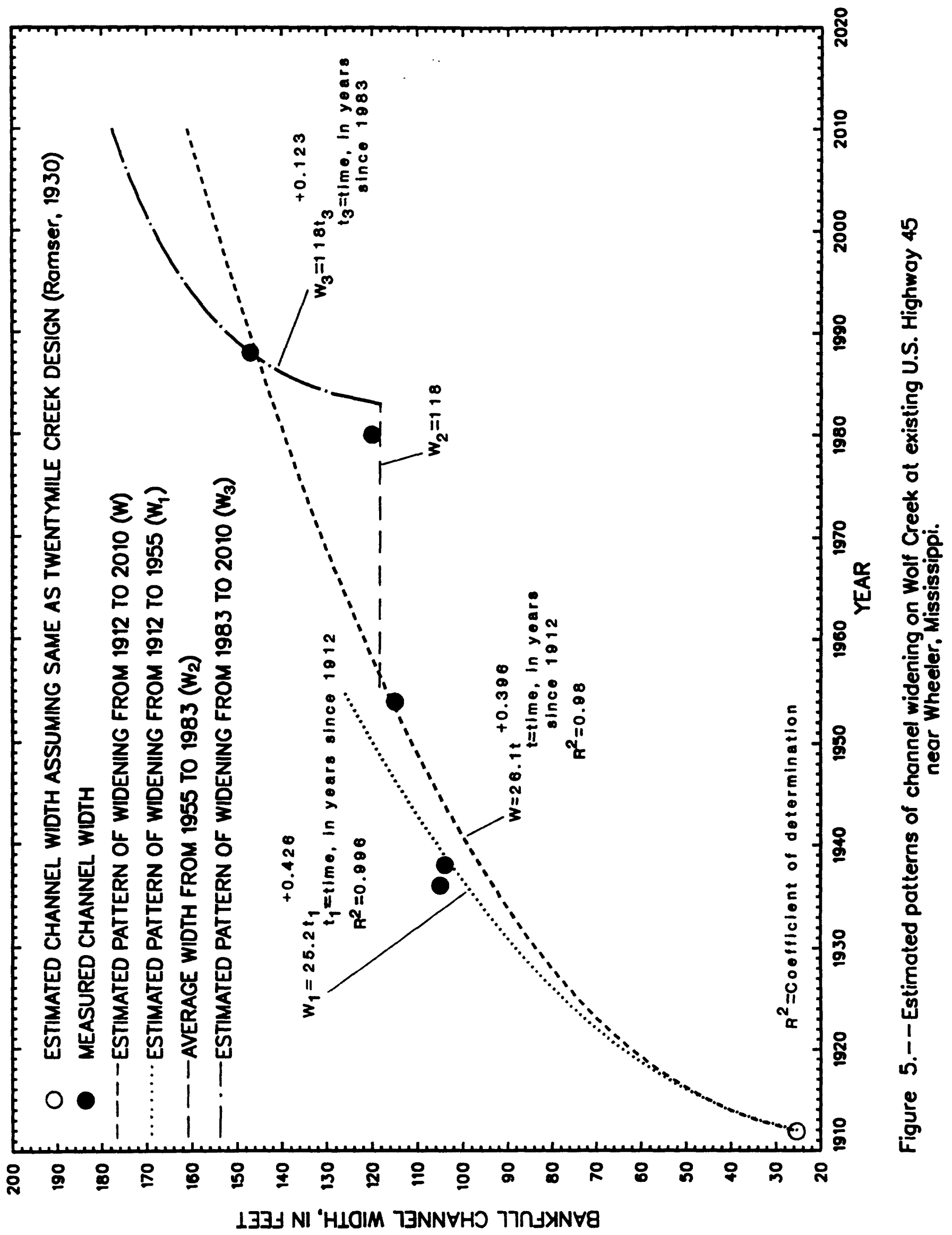




\section{Wolf Creek North Tributary}

The slough-line angle and the temporary angle of stability were extended on a channel cross section on Wolf Creek north tributary located about $550 \mathrm{ft}$ downstream from the proposed relocation to estimate additional widening during the next 10 to 20 years. About 5 to $10 \mathrm{ft}$ of additional widening was projected; however, it is likely that this will occur over a longer period of time than 20 years because of the stability of the banks.

\section{SUMMARY}

The channel of Wolf Creek at existing U.S. Highway 45 near Wheeler, Mississippi, has degraded about $8 \mathrm{ft}$ and widened about $122 \mathrm{ft}$ since 1912. As much as $3 \mathrm{ft}$ of further degradation and $30 \mathrm{ft}$ of additional widening could occur on Wolf Creek at existing U.S. Highway 45 and at the proposed U.S. Highway 45 relocation through the year 2010. No significant further degradation through the year 2010 is expected on Wolf Creek north tributary at the proposed U.S. Highway 45 relocation. The channel width of Wolf Creek north tributary at the proposed relocation could increase about $10 \mathrm{ft}$ in the next 10 to 20 years. These projections are based on the assumption that no additional channel modifications and no unusually large and destructive flooding will occur by the year 2010. 


\section{REFERENCES}

Cernica, J.N., 1982, Geotechnical Engineering: CBS College Publishing, $488 \mathrm{p}$.

Das, B.M., 1984, Principles of foundation engineering: Wadsworth, Inc., $595 \mathrm{p}$.

Handy, R.L., 1981, Borehole shear test, instructions version 9-81: Ames, lowa, Handy Geotechnical Instruments, Inc., $26 \mathrm{p}$.

Handy, R.L., and Fox, N.W., 1967, A soil bore-hole direct-shear device: Highway Research News No. 27, p. 42-51.

Huang, Y.H., 1983, Stability analysis of earth slopes: Van Nostrand and Co., $305 \mathrm{p}$.

Hupp, C.R., 1987, Determination of bank widening and accretion rates and vegetation recovery along modified West Tennessee streams in International Symposium Proceedings of Ecological Aspects of Tree-Ring Analysis: Department of Energy Conference 8608144, p. 224-233.

-1988, Plant ecological aspects of flood geomorphology and paleoflood history: Flood Geomorphology, John Wiley and Sons, Inc., p. 335-356.

Mississippi Board of Development, 1940a, Itawamba County Twenty Mile Drainage District, Itawamba County," Mississippi: W.P.A. Project No. 5483, Statewide Drainage Survey, 6 p.

-1940b, Prentiss County Twenty Mile Drainage District, Prentiss County, Mississippi: W.P.A. Project No. 5483, Statewide Drainage Survey, 9 p.

-1940c, Wolf Creek Drainage District, Prentiss County, Mississippi: W.P.A. Project No. 5483, Statewide Drainage Survey, $4 \mathrm{p}$.

-----1940d, Wolfe Creek Sub-drainage District No. 1, Prentiss County, Mississippi: W.P.A. Project No. 5483, Statewide Drainage Survey, $4 \mathrm{p}$.

Ramser, C.E., 1930, Erosion and silting of dredged drainage ditches: U.S. Department of Agriculture, Technical Bulletin 184, Washington, D.C., 55 p.

Sigafoos, R.S., 1964, Botanical evidence of floods and floodplain deposition: U.S.
Geological Survey Professional Paper 485-A, p. A1-A33.

Simon, Andrew, and Hupp, C.R., 1986a, Channel-widening characteristics and bank slope development along a reach of Cane Creek, West Tennessee, in Subitzky, Seymour, ed., Selected Papers in the Hydrologic Sciences: U.S. Geological Survey Water-Supply Paper 2290, p. 113-126.

--1986b, Channel evolution in modified Tennessee channels in Proceedings 4th Inter-Agency Sedimentation Conference, Las Vegas, p. 71-82.

-.---1987, Geomorphic and Vegative recovery processes along modified Tennessee streams: An interdisciplinary approach to disturbed fluvial streams in forest hydrology and watershed management: IAHS Publication no. 167.

Sowers, G.F., 1979, Introductory soil mechanics and foundations: Geotechnical engineering (4th edition): MacMillan Publishing Co., Inc., $621 \mathrm{p}$.

Spangler, M.G., and Handy, R.L., 1973, Soil engineering (3rd edition): New York and London, Intext Educational, 748 p.

Thornbury, W.E., 1965, Regional, geomorphology of the United States: John Wiley and Sons, Inc., 609 p.

Thorne, C.R., Murphey, J.B., and Little, W.C., 1981, Stream channel stability, Appendix D, Bank stability and bank material properties in the bluffline streams of northwest Mississippi: Oxford, Miss., U.S. Department of Agriculture, Sedimentation Laboratory, $257 \mathrm{p}$.

Turnipseed, D. P., and Wilson, K.V., Jr., (1990), Channel and bank stability of Twentymile Creek at U.S. Highway 45 near Wheeler, Prentiss County, Mississippi: U.S. Geological Survey Open-File Report 90-111, 16 p.

U.S. Army Corps of Engineers, Mobile District, 1983, Bank stabilization project Twenty-mile Creek interim measures, Lee, Prentiss, and Itawamba Counties: U.S. Army Corps of Engineers Design Report. 
Wilson, K.V., Jr., and Turnipseed, D.P:, 1989a, Channel and bank stability of Big Black River Canal tributary at U.S. Highway 82 at Stewart, Montgomery County, Mississippi: U.S. Geological Survey Open-File Report 89-35, 16 p.

-1989b, Channel and bank stability of selected streams in northern Mississippi: Mississippi Water Resources Conference Proceedings, 1989. 